\title{
FT-IR for Rapid Discrimination of Halophilic Archaea and Bacteria
}

\author{
Kıymet Güven ${ }^{1 *}$, Gülşah Albayrak ${ }^{1}$, Alaettin Güven ${ }^{2}$ and Berna Yazıc ${ }^{3}$ \\ ${ }^{1}$ Department of Biology, Faculty of Science, Anadolu University, Eskişehir, 26470, Turkey \\ ${ }^{2}$ Department of Chemistry, Faculty of Science, Anadolu University, Eskişehir, 26470, Turkey \\ ${ }^{3}$ Department of Statistics, Faculty of Science, Anadolu University, Eskişehir, 26470, Turkey
}

"Corresponding author: Kıymet Güven, Department of Biology, Faculty of Science, Anadolu University, Eskişehir, 26470, Turkey, Tel: +90 (222) 335 0580/4724; Fax: +90(222)3204910; E-mail: kguven@anadolu.edu.tr

Rec date: Feb 15, 2015; Acc date: Mar 14, 2015; Pub date: Mar 23, 2015

Copyright: ( 2015 Güven K, et al. This is an open-access article distributed under the terms of the Creative Commons Attribution License, which permits unrestricted use, distribution, and reproduction in any medium, provided the original author and source are credited.

\section{Abstract}

Fourier transform infrared spectroscopy (FT-IR) was applied for the first time for the discrimination of halophilic prokaryotes. In the current study, halophilic Bacteria and Archaea species were investigated according to their FT-IR profiles. Some of the halophilic isolates collected from Çamaltı Saltern in Turkey were also analyzed and their FT-IR profiles were compared with reference strains. Hierarchical cluster analysis was used to indicate discrimination. This study implies that FT-IR can be applied to discriminate species of Archae and Bacteria.

Keywords: Halophilic; Bacteria; Archaea; Fourier transform infrared spectroscopy

\section{Introduction}

Microorganisms requiring salt for growth and specialized for living in hypersaline environments are referred as halophiles. Kushner (1985) defined several categories of microorganisms according to the salt concentration that was optimal for growth. These organisms are phylogenetically (on the basis of comparative ribosomal RNA gene sequencing) found in all three domains of life: Archaea, Bacteria and Eukarya, the domain being the highest taxon. Two of these domains, the Archaea and Bacteria, are exclusively microbial and are composed of single cells that lack a membrane-enclosed nucleus (i.e., prokaryotic cells) [1].

Halophilic microorganisms able to live in saline environments have garnered a great deal of attention as they have the potential in various biotechnological applications such as the production of biopolymers, compatible solutes, cancer detection, drug screening, biodegradation of toxic compounds, fermentation of foods and most importantly the production of enzymes [2-4].

Most of the halophilic Archaea are found in hypersaline lakes and saltern crystallizer ponds, giving a red coloration due to C-50 carotenoid pigments. However, the domain Bacteria contains many types of halophilic and halotolerant microorganisms in many phylogenetic subgroups [5].

Although the domains Archaea and Bacteria are founded on phylogenetic criteria, these two domains can also be characterized by phenotypic properties, e.g. membrane lipids [6]. In contrast to the lipids of Bacteria in which ester linkages bond fatty acids to glycerol, the lipids of Archae contain ether bonds between glycerol and their hydrophobic side chains [7].

The diversity of Archaea and Bacteria in various hypersaline environments worldwide has been characterized by culture-based, pigment and molecular-phylogenetic studies [7-12]. It is known that halophilic Archaea are mostly orange-red pigmented and grow optimally at salt concentrations from above $20 \%$ [13]. Archaeal strains grow in the presence of penicillin $G$ in the growth medium, whereas Bacterial strains could not [7]. However, the more recent technique using Archaeal and Bacterial primers in PCR has proved itself as a more reliable way of distinguishing between the two domains [14-15].

Conventional techniques for identifying microorganisms are phenotypic, biochemical or genotypic assays including culturing, immunological methods such as the enzyme-linked immunosorbent assay (ELISA), and molecular biology techniques such as polymerase chain reaction (PCR) and in-situ hybridization. These techniques are accurate, but none of these techniques are readily automated for rapid $(<1 \mathrm{~min})$ identification under industrial or field conditions [16]. However, the FT-IR method is rapid and non-invasive, permitting users to collect full spectra in a few seconds per sample. Differences in the structure and quantity of cell wall polysaccharides, lipids and proteins are reflected in the FT-IR spectra. These data provide fingerprint-like patterns which are highly reproducible and typical for different bacteria [17-19]. Compared to conventional methods, FT-IR identification is not only based on cell characteristics, but is achieved by selecting discriminating features from a large amount of spectral information. The technique is applicable to all microorganisms including prokaryotes and eukaryotes (e.g. fungi) that can be grown in culture [20].

Identification with FT-IR has been used for the identification of various members of Bacteria at the genus, species, and even strain level and typical examples are given in Table 1 [21-49]. However, there has been no such study of Archaea except for one study by Hedrick et al. [6] who used diffuse reflectance FT-IR spectroscopic analysis for the rapid differentiation of Archaea from Bacteria.

Therefore, in this study, we aimed to investigate the similarities and differences between some representatives of halophilic Archaea and Bacteria domains, and if possible to differentiate between genera and species using FT-IR spectroscopy. To our knowledge, this is the first study to investigate FT-IR differentiation of halophilic prokaryotes. 
Citation: Güven K, Albayrak G, Güven A, Yazic B (2015) FT-IR for Rapid Discrimination of Halophilic Archaea and Bacteria. J Phylogen

Page 2 of 7

\section{Materials and Methods}

\section{Organisms}

A total of twelve halophilic reference strains representing Archaea and Bacteria domains were kindly provided by Josefa Anton (Spain), Michael Dyall-Smith (Australia), Helga Stan-Lotter (Austria) and Dr. Mehmet Burçin Mutlu (Anadolu University, Turkey). The strains used and their sources are given in Table 2 .

\begin{tabular}{|c|c|c|}
\hline Microorganisms & Year & Reference \\
\hline $\begin{array}{l}\text { Staphylococcus, Streptococcus, Clostridium, } \\
\text { Legionella species and Escherichia coli }\end{array}$ & 1990 & Helm et al. [21] \\
\hline $\begin{array}{l}\text { Bacillus cereus, Bacillus mycoides, Bacillus } \\
\text { thrungiensis }\end{array}$ & 1998 & Beattie et al. [22] \\
\hline Candida albicans & 2000 & Orsini et al. [18] \\
\hline $\begin{array}{l}\text { Pseudomonas aeruginosa, Pseudomonas } \\
\text { fluorescens, Pseudomonas putida, and } \\
\text { Pseudomonas stutzeri }\end{array}$ & 2001 & Filip et al. [23] \\
\hline & 2003 & Guibet et al. [24] \\
\hline $\begin{array}{l}\text { Listeria monocytogenes ATCC 19114, L. } \\
\text { innocua ATCC 51742, L. innocua ATCC 33090, } \\
\text { and L. monocytogenes ATCC } 7644\end{array}$ & 2004 & Lin et al. [25] \\
\hline $\begin{array}{l}\text { Streptococcus crista, Strep. Salivarius and } \\
\text { Strep. Rattus }\end{array}$ & 2004 & $\begin{array}{l}\text { van der Mei et al } \\
{[26]}\end{array}$ \\
\hline Bacillus subtilis & 2004 & Filip et al. [27] \\
\hline $\begin{array}{l}\text { Lactobacillus, L. sakei, L. plantarum, L. curvatus } \\
\text { and L. paracasei }\end{array}$ & 2004 & Oust et al. [28] \\
\hline Acinetobacter species & 2004 & Winder et al. [29] \\
\hline $\begin{array}{l}\text { Candida albicans, Candida glabrata, Candida } \\
\text { parapsilosis, Candida tropicalis, Candida krusei, } \\
\text { and Candida kefyr }\end{array}$ & 2005 & $\begin{array}{l}\text { Essendoubi et al } \\
{[30]}\end{array}$ \\
\hline $\begin{array}{l}\text { Bacillus cereus, Salmonella enterica, } \\
\text { Escherichia coli and Listeria spp. }\end{array}$ & 2006 & Al-Holy et al. [31] \\
\hline Campylobacter coli and Campylobacter jejuni. & 2006 & Mouwen et al. [32] \\
\hline $\begin{array}{l}\text { S. arlettae, S. capitis, S. caprae, S. carnosus, S. } \\
\text { epidermis, S. equorum, S. felis, S. gallinarum, } \\
\text { S. lentus, S. intermedius, S. pasteuri, S. } \\
\text { pulvereri }\end{array}$ & 2006 & Lamprell et al. [33] \\
\hline $\begin{array}{l}\text { Enterobacter aerogenes, Enterobacter cloacae, } \\
\text { Klebsiella spp., Citrobacter koseri; Proteus } \\
\text { mirabilis, Escherichia coli, Staphylococcus } \\
\text { aureus, Staphylococcus epidermidis, } \\
\text { Enterococcus faecalis, and Enterococcus } \\
\text { faecium }\end{array}$ & 2006 & Sandt et al. [34] \\
\hline $\begin{array}{l}\text { Lactobacillus, Lactococcus, Leuconostoc, } \\
\text { Pediococcus and Streptococcus strains }\end{array}$ & 2007 & Dziuba et al. [35] \\
\hline Listeria monocytogenes samples & 2006 & Oust et al. [36] \\
\hline Staphylococcus aureus & 2007 & Amiali et al. [37] \\
\hline Mesophilic and termophilic bacteria & 2007 & Garip et al. [38] \\
\hline $\begin{array}{l}\text { Listeria innocua FH, Lactococcus lactis, } \\
\text { Pseudomonas fluorescens, Pseudomonas } \\
\text { mendocina and Pseudomonas putida }\end{array}$ & 2008 & $\begin{array}{l}\text { Alexandrakis et al } \\
{[39]}\end{array}$ \\
\hline
\end{tabular}

\begin{tabular}{|l|l|l|}
\hline $\begin{array}{l}\text { Acinetobacter baumanni, Enterococcus faecium } \\
\text { and Staphylococcus aureus / epidermidis }\end{array}$ & 2008 & Preisner et al. [40] \\
\hline $\begin{array}{l}\text { Bacillus cereus, B. megaterium, B. subtilis, B. } \\
\text { thrungiensis }\end{array}$ & 2009 & Forrester et al. [41] \\
\hline Bacillus cereus & 2010 & Mietke et al. [42] \\
\hline Filamentous fungi and yeasts & 2010 & Santos et al. [43] \\
\hline Lactic acid bacteria & 2011 & Samelis et al. [44] \\
\hline E. coli O157:H7 & 2012 & Davis et al. [45] \\
\hline Salmonella enterica & 2012 & Preisner et al. [46] \\
\hline Trichophyton & 2013 & Ergin et al. [47] \\
\hline Staphylococcus aureus & 2014 & \\
\hline Filamentous Fungi & 2015 & \\
\hline
\end{tabular}

Table 1: Examples of application of FT-IR for microbial identification.

\begin{tabular}{|c|c|c|c|}
\hline \multicolumn{4}{|l|}{ Reference strains } \\
\hline Archaea & Source & Bacteria & Source \\
\hline Haloferax mediterranei & $\begin{array}{l}\text { Josefa Anton, } \\
\text { Spain }\end{array}$ & $\begin{array}{l}\text { Halomonas } \\
\text { elongata }\end{array}$ & $\begin{array}{l}\text { Josefa Anton, } \\
\text { Spain }\end{array}$ \\
\hline Haloferax alexandrinus & $\begin{array}{l}\text { M. Burcin Mutlu, } \\
\text { Turkey }\end{array}$ & $\begin{array}{l}\text { Pseudomonas } \\
\text { halophila DSM } \\
3050\end{array}$ & $\begin{array}{l}\text { Josefa Anton, } \\
\text { Spain }\end{array}$ \\
\hline Haloarcula hispanica & $\begin{array}{l}\text { Michael Dyall- } \\
\text { Smith, Australia }\end{array}$ & $\begin{array}{l}\text { Chromahalobact } \\
\text { er salexigens }\end{array}$ & $\begin{array}{l}\text { Josefa Anton, } \\
\text { Spain }\end{array}$ \\
\hline Haloarcula mukohatei & $\begin{array}{l}\text { M. Burcin Mutlu, } \\
\text { Turkey }\end{array}$ & $\begin{array}{l}\text { Salinibacter } \\
\text { ruber }\end{array}$ & $\begin{array}{l}\text { Josefa Anton, } \\
\text { Spain }\end{array}$ \\
\hline Haloarcula marismortui & $\begin{array}{l}\text { M. Burcin Mutlu, } \\
\text { Turkey }\end{array}$ & s & \\
\hline $\begin{array}{l}\text { Haloarcula } \\
\text { argentinensis }\end{array}$ & $\begin{array}{l}\text { M. Burcin Mutlu, } \\
\text { Turkey }\end{array}$ & & \\
\hline $\begin{array}{l}\text { Halococcus } \\
\text { dombrowskii }\end{array}$ & $\begin{array}{l}\text { Helga Stan- } \\
\text { Lotter, Austria }\end{array}$ & & \\
\hline $\begin{array}{l}\text { Halorubrum } \\
\text { xinjiangense }\end{array}$ & $\begin{array}{l}\text { M. Burcin Mutlu, } \\
\text { Turkey }\end{array}$ & & \\
\hline \multicolumn{4}{|l|}{ Çamalti strains } \\
\hline \multicolumn{2}{|l|}{ Archaea } & \multicolumn{2}{|l|}{ Bacteria } \\
\hline \multicolumn{2}{|l|}{$\mathrm{C} 23$} & \multicolumn{2}{|l|}{ C15 } \\
\hline \multicolumn{2}{|l|}{$\mathrm{C} 27$} & \multicolumn{2}{|l|}{$\mathrm{C} 18$} \\
\hline \multicolumn{2}{|l|}{ C29 } & \multicolumn{2}{|l|}{$\mathrm{C} 19$} \\
\hline \multicolumn{2}{|l|}{ C37 } & \multicolumn{2}{|l|}{ C21 } \\
\hline \multicolumn{2}{|l|}{$\mathrm{C} 43$} & \multicolumn{2}{|l|}{ C22 } \\
\hline \multicolumn{2}{|l|}{ C46 } & & \\
\hline \multicolumn{2}{|l|}{ C50 } & & \\
\hline \multicolumn{2}{|l|}{ C51 } & & \\
\hline
\end{tabular}


C52

Table 2: Halophilic Archaea and Bacteria strains used in the study.

Nine of the Archeal and five of the Bacterial strains isolated from the Çamaltı solar saltern in Turkey for a previous study were also included in the assay (Table 2). Domain tests of these isolates were carried out by PCR amplification of $16 \mathrm{~S}$ rRNA genes using universal primers for Bacteria and Archaea, as indicated by Mutlu et al [12].

Growth Media. Halophilic microorganisms were grown on sea water agar $(25 \% \mathrm{SW})$ containing $\left(\mathrm{g} \mathrm{L}^{-1}\right): \mathrm{NaBr} 0.65, \mathrm{NaHCO}_{3} 0.17, \mathrm{KCl}$ 5, $\mathrm{CaCl}_{2}$ 0.72, $\mathrm{MgSO}_{4} \bullet 7 \mathrm{H}_{2} \mathrm{O} 49.5, \mathrm{MgCl}_{2} \bullet 6 \mathrm{H}_{2} \mathrm{O}$ 34.6, $\mathrm{NaCl} 195,1 \mathrm{~g}$ yeast extract (YE), and $20 \mathrm{~g}$ of agar, for one week at $37^{\circ} \mathrm{C}$. Two loops of massive growth were then placed in Eppendorf tubes.

Sample Preparation. Cells were collected and dried in a vacuum evaporator at room temperature and then were ground into fine particles using a mortar and pestle. About one milligram of biomass was encapsulated in 100 milligrams $\mathrm{KBr}$ with a pressure of $100 \mathrm{~kg} / \mathrm{cm}^{2}$ (2000 psi) in order to prepare the sample pellet. Three sample pellets were prepared for each microorganism tested.

\section{Fourier transform infrared spectroscopy and data analysis}

Infrared spectra were obtained by scanning the pellets with a Perkin Elmer Spectrum 100. The spectrum of air was recorded as the background and subtracted automatically using the spectrum software program. Atmospheric vapour was also automatically subtracted. The FT-IR spectra of bacterial samples were recorded in the $4000-450 \mathrm{~cm}^{-1}$ region at room temperature. Three spectra were acquired for each bacterial sample.

The averages of the spectra belonging to the same strain, baseline correction, normalization and the bands were obtained by the software. The average spectra and normalization process were applied only for visual representation of the differences; however, for the determination of the spectral parameters and calculation of mean values and statistical analyses, each baseline-corrected original spectrum was taken into consideration.

\section{Statistical analysis}

The features that reflect the important characteristics of different biochemical components was taken into account while assessing the significant values in spectra. Hierarchical cluster analysis was applied to classify the differences in samples by using Clustan 8.0 software. For calculating the spectral pair-wise distance, the Euclidian distance was used in the $4000-450 \mathrm{~cm}^{-1}$ region. Average Linkage (UPGMA) method was used to join the clusters together.

\section{Results}

In this study, FT-IR spectroscopy was carried out on halophilic members of the Archaea and Bacterial domains and spectral differences and similarities were compared between the domains and species.

The FT-IR spectra of reference strains of Archaea are shown in Figure 1. As can be seen from the figure, there were differences mainly in the $450-1700 \mathrm{~cm}^{-1}$ region. Table 3 shows the regions numbered from 1 to 6 to discriminate Archaeal members. All of the Archaeal strains showed ether bonds $(\mathrm{C}-\mathrm{O})$ in the $1000-1300 \mathrm{~cm}^{-1}$ region. Also,
$\mathrm{CH}_{2}$ asymmetric stretching of methylene groups in fatty acids was observed at $2930 \mathrm{~cm}^{-1}$ as broadened peaks (peak no. 1).

The FT-IR spectra of Bacteria strains are given in Figure 2. As can be seen in the figure, there were differences mainly in the 1000-1700 $\mathrm{cm}^{-1}$ region, and typically strong ester bonds in the $1735-1750 \mathrm{~cm}^{-1}$ region.

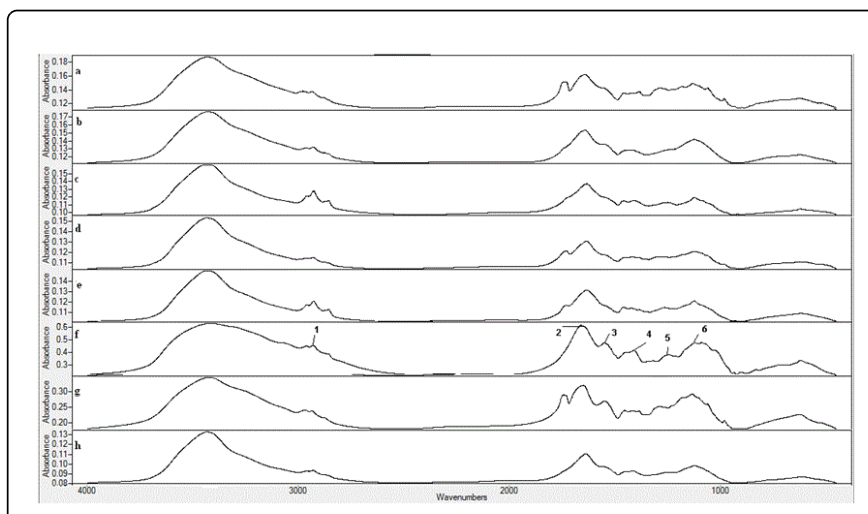

Figure 1: FT-IR spectra of strains belonged to Archaea domain. a: Haloferax mediterranei, b. Haloferax alexandrinus, c. Haloarcula hispanica, d. Haloarcula mukohatei, e. Haloarcula morismortii, f. Haloarcula argentinensis, g. Halococcus dombrowski, h. Halorubrum xinjiangense.

\begin{tabular}{|l|l|l|}
\hline $\begin{array}{l}\text { Peak } \\
\text { numbe } \\
\mathbf{r}\end{array}$ & $\begin{array}{l}\text { Wavenumbe } \\
\mathbf{r s} \\
\left(\mathbf{c m}^{-1} \mathbf{)}\right.\end{array}$ & Functional group assignments and remarks \\
\hline 1 & 2929.25 & $\begin{array}{l}\mathrm{CH}_{2} \text { asymmetric stretch: methylene groups in fatty } \\
\text { acids }\end{array}$ \\
\hline 2 & 1659.46 & Amide I (protein CO stretching): a helices \\
\hline 3 & 1549.2 & Amide II (protein N-H bend, C-N stretch): $\alpha$ helices \\
\hline 4 & 1410.48 & Symmetric CO 2 streching \\
\hline 5 & 1243.31 & Aromatic ether band \\
\hline 6 & 1102 & C-O stretch, ether band \\
\hline
\end{tabular}

Table 3: Comporison of halophilic reference Archaea species.

A strong peak indicating amide group $\mathrm{N}-\mathrm{H}$ stretching at $3200 \mathrm{~cm}^{-1}$ (peak no. 1) was observed (Figure 2) $\mathrm{CH}_{2}$ asymmetric stretching of methylene groups in fatty acids were observed at $2960 \mathrm{~cm}^{-1}$ as narrow peaks (peak no. 2-3). Table 4 shows regions 1 to 7 in Figure 2 used to discriminate Archaeal members. Hierarchical cluster analyses on FTIR spectra from the reference Archaea and Bacteria strains resulted in the dendrogram shown in Figure 3.

\section{Comparison of strains isolated from the camaltı saltern}

The bands centered at $1000-1300 \mathrm{~cm}^{-1}$ corresponds to the C-O stretching of ether groups (Figure 4) for Archaeal strains obtained from the Çamaltı solar saltern. A strong band occurred at 1735-1750 $\mathrm{cm}^{-1}$ corresponding to $\mathrm{C}=\mathrm{O}$ stretching of the esters (Figure 5) in Bacterial strains obtained from the Çamaltı solar saltern. Hierarchical 
Citation: Güven K, Albayrak G, Güven A, Yazic B (2015) FT-IR for Rapid Discrimination of Halophilic Archaea and Bacteria. J Phylogen

cluster analyses of the FT-IR spectra from Çamaltı strains of Archaea and Bacteria resulted in the dendrogram shown in Figure 6.

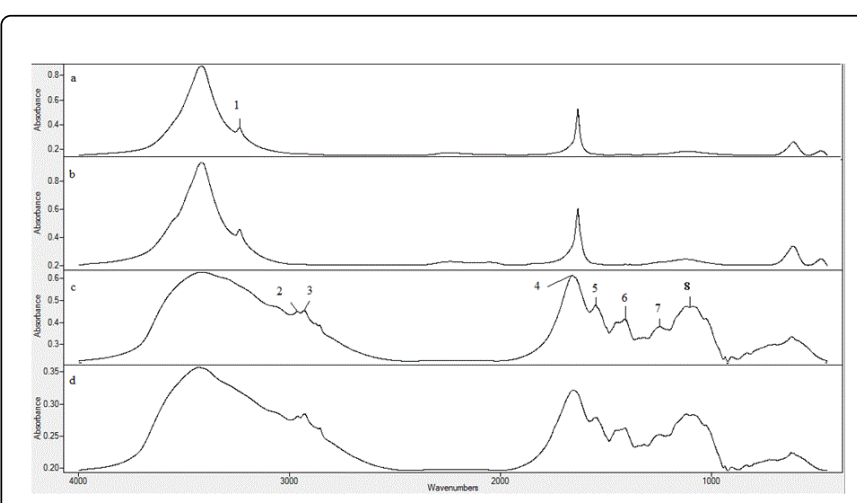

Figure 2: Discrimination between reference bacteria species: a: Chromahalobacter salexigens, b: Salinibacter ruber, c: Halomonas elongata, d: Pseudomonas halophila.

The spectra were analyzed for the differentiation of each genus/ species. The FT-IR spectra for known examples of each class of bacteria were collected. These were used to generate a discrimination method based on the assignment of spectra to classes. As with any biological sample, there was considerable variation within each class, so region selection and spectral processing were critical.

Clear segregations between different domains, genera and species of bacteria were observed by hierarchical cluster analyses by using Clustan 8.0. Euclidean distances were taken into account.

\section{Discussion}

In this study, we used a spectroscopic approach for the rapid discrimination and identification of halophilic microorganisms. These extreme microorganisms are important for their newly discovered biotechnological purposes.

\begin{tabular}{|l|l|l|}
\hline $\begin{array}{l}\text { Peak } \\
\text { numbe } \\
\mathbf{r}\end{array}$ & $\begin{array}{l}\text { Wavenumb } \\
\text { er }\end{array}$ & Functional group assignments and remarks \\
\hline 1 & 3235,74 & Amide group $\mathrm{N}-\mathrm{H}$ streching \\
\hline 2 & 2965,51 & Aromatic $\mathrm{C}-\mathrm{H}$ \\
\hline 3 & 2930,41 & $\begin{array}{l}\mathrm{CH}_{2} \text { asymmetric stretch: methylene groups in fatty } \\
\text { acids }\end{array}$ \\
\hline 4 & 1735 & $\mathrm{C}=\mathrm{O}$ stretch, ester group \\
\hline 5 & 1547,67 & Amide II (protein N-H bend, C-N \\
\hline 6 & 1410,79 & Symmetric $\mathrm{CO}_{2}$ streching \\
\hline 7 & 1249,36 & ring C-H in- plane bending vibrations \\
\hline 8 & 1101,96 & C-O streching, ester group \\
\hline
\end{tabular}

Table 4: Comporison of halophilic reference Bacteria species.

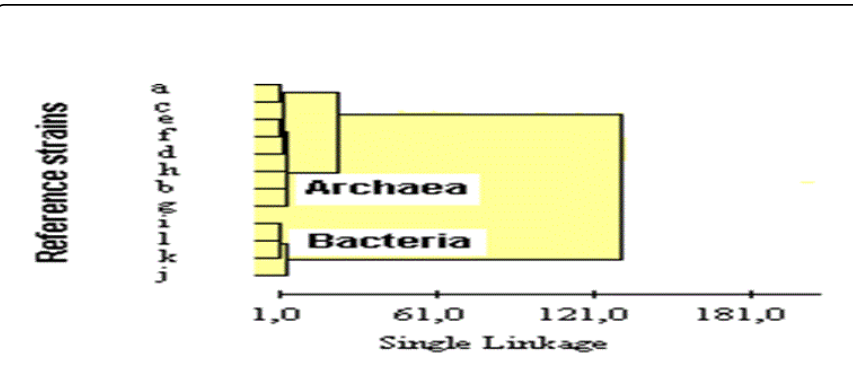

Figure 3: Classification of FT-IR spectra obtained from different strains of halophilic Archaea and Bacteria domains. Dendogram shows the dissimilarity level of strains tested by Clustan 8 . Abbreviation: a: Haloarcula argentinensis, b: Haloarcula mukohatei, c: Haloarcula hispanica, d: Haloferax alexandrines, e: Haloarcula marismortui, f: Halorubrum xinjiangense, g: Halococcus dombrowskii, h: Haloferax mediterranei, i: Chromahalobacter salexigens, j: Halomonas elongata, $\mathrm{k}$ : Pseudomonas halophila, 1: Salinibacter ruber.

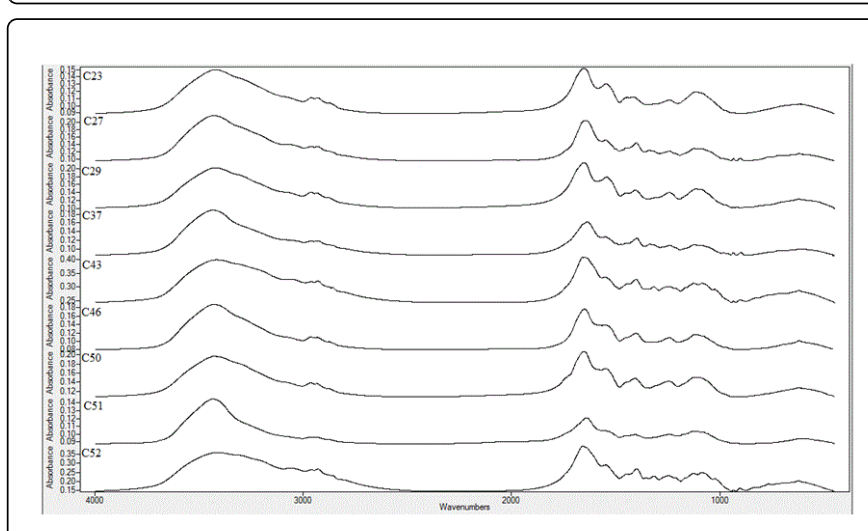

Figure 4: FT-IR Spectra of Archaeal strains obtained from Çamaltı saltern.

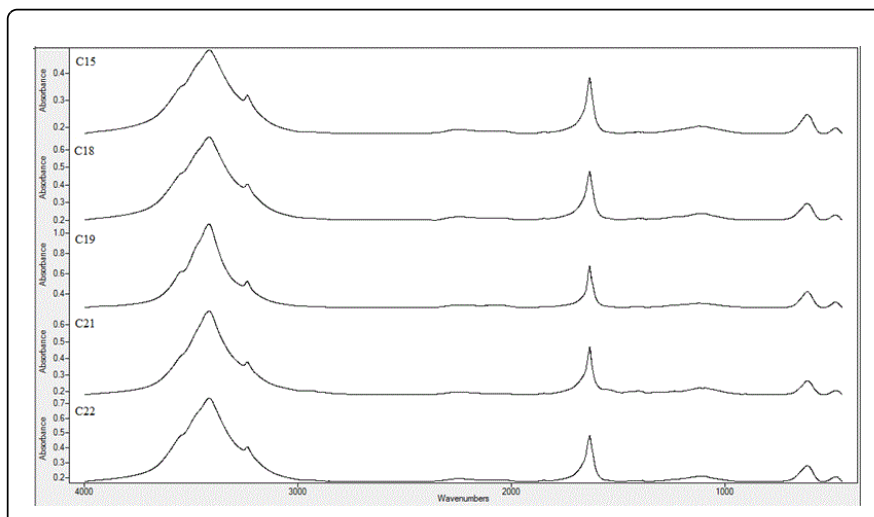

Figure 5: FT-IR Spectra of Bacterial strains obtained from Çamaltı saltern. 


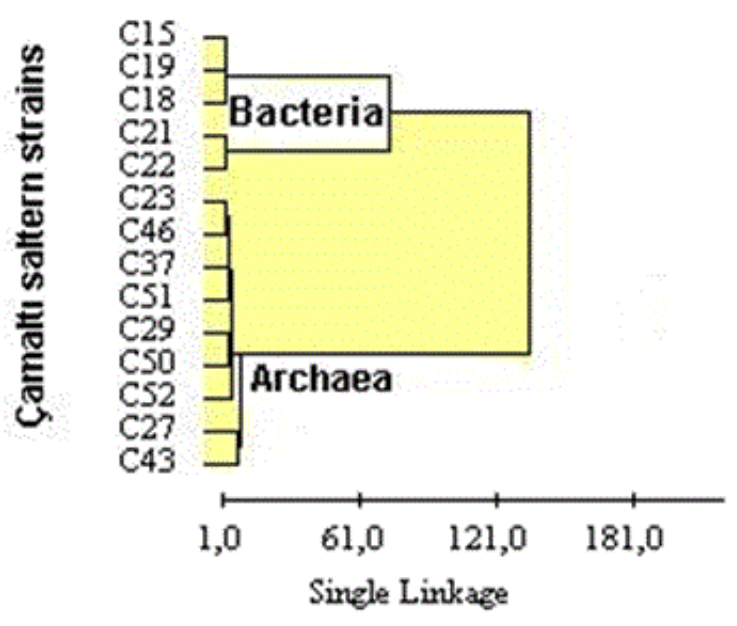

Figure 6: Classification of FT-IR spectra obtained from Çamaltı strains of halophilic Archaea and Bacteria domains. Dendogram shows the dissimilarity level of strains tested by Clustan 8 . Strains numbered from $\mathrm{C} 15$ to $\mathrm{C}-52$ were isolated from Çamaltı saltern.

Traditional methods used for the identification of various microorganisms are based on morphological characteristics, biochemical reactions, serological reactions, sensitivity to bacteriophages and 16s rDNA sequencing. However, these methods can often be tedious, time consuming and occasionally inconclusive [38].

The only study on the rapid differentiation of archaebacteria from eubacteria by diffuse reflectance FT-IR spectroscopic analysis of lipid preparations was carried out by Hedrick et al. [6]; the authors concluded that archaebacterial ether lipids had broadened peaks in the alkyl region between 2800-3000 $\mathrm{cm}^{-1}$; however, eubacterial spectra were narrower and clearly separate [39]. It is known that ether bonds (C-O) appear in the $1000-1300 \mathrm{~cm}^{-1}$ region (http://www2ups.edu/ faculty/hanson/spectroscopy/IR/IRfrequencies.html). We also observed that archaeal strains gave ether bands in this region; however, both reference and Çamaltı saltern bacterial strains had typically a strong ester bonds in the $1735-1750 \mathrm{~cm}^{-1}$ region.

The application of various vibrational spectroscopic techniques to identify and characterize microorganisms has been studied with Fourier transform infrared (FT-IR) spectroscopy are the most promising. FT-IR spectroscopy is a rapid and non-destructive technique that has been demonstrated to provide a highly sensitive and reproducible means for the identification of microorganisms without the use of reagents. Furthermore, it can provide results faster than virtually any other conventional method in microbiology, which are generally time consuming and labour intensive. Moreover, FT-IR identification methods have easy and simple protocols together with low running costs [50]. Infrared spectroscopy is based on the measurement of molecular vibrations [51]. Fourier transform infrared spectroscopy with high-resolution power is able to distinguish microbial cells at different taxonomic levels [52]. This technique is referred to as whole-organism fingerprinting because it measures the vibrations of chemical bonds within the biochemical constituents of cells [6]. The chemical composition of the cell contributes to the FT-IR spectrum [22]. As microorganisms consist of pure biochemicals, the IR spectra of these microorganisms provide few features and peaks since the bonds and functional groups of a particular molecular structure are often give a simple, unique, and reliable spectral fingerprint. The IR vibrations of microorganisms are related to thousands of other molecular components in microorganisms. With the use of different statistical methods like principal component analysis (PCA), hierarchical cluster analysis (HCA), partial least square regression (PLSR), soft independent modelling of class analogy (SIMCA), K-nearest neighbor (KNN), artificial neural networks (ANNs) and canonical variate analysis (CVA), extracting subtle details from the IR spectra of whole microbial samples has become possible. This method has been successfully applied to correlate the nearest neighbor along appropriate taxa [53-54]. In this study, clear segregations between different domain, genera and species of bacteria were observed by hierarchical cluster analyses.

In conclusion, identification of halophilic microorganisms using FT-IR seems to have great value, confirming that FT-IR can detect biochemical differences between halophilic prokaryotic cells in this preliminary study. However, future studies should be carried out to optimize the results by including many reference strains and environmental isolates.

This study has contributed basic data to the FT-IR studies of halophilic prokaryotes and the method could become a potentially useful tool for rapid differentiation of domains of Archaea and Bacteria at the strain level.

\section{Acknowledgments}

The authors thank Josefa Anton from Spain, Michael Dyall-Smith from Australia, Helga Stan-Lotter from Austria and Dr. Mehmet Burçin Mutlu from Turkey for supplying the cultures for the study.

\section{References}

1. Madigan M, Martinko JM, Dunlap PV, Clark DP (2009) Biology of microorganism. Pearson Education, Inc: San Fransisco, USA, pp.1061

2. Ventosa A, Nieto JJ (1995) Biotechnological applications and potentialities of halophilic microorganisms. World J Microbiol Biotechnol 11: 85-94.

3. Margesin R, Schinner F (2001) Potential of halotolerant and halophilic microorganisms for biotechnology. Extremophiles 5: 73-83.

4. Asad S, Amoozegar MA, Pourbabaee AA, Sarbolouki MN, Dastgheib SM (2007) Decolorization of textile azo dyes by newly isolated halophilic and halotolerant bacteria. Bioresour Technol 98: 2082-2088.

5. Oren A (2002) Diversity of halophilic microorganisms: environments, phylogeny, physiology, and applications. J Ind Microbiol Biotechnol 28: 56-63.

6. Hedrick DB, Nivens DE, Stafford C, White DC (1991) Rapid differentiation of Archaebacteria from eubacteria by diffuse reflectance Fourier transform infrared spectroscopic analysis of lipid preparations. J Microbiol Meth 13: 67-73.

7. Oren A, Ventosa A, Grant WD (1997) Proposed minimal standards for description of new taxa in the order Halobacteriales. Int J Syst Bacteriol 47: 233-238.

8. Vreeland RH, Piselli AF Jr, McDonnough S, Meyers SS (1998) Distribution and diversity of halophilic bacteria in a subsurface salt formation. Extremophiles 2: 321-331.

9. Ventosa A, Márquez MC, Garabito MJ, Arahal DR (1998) Moderately halophilic gram-positive bacterial diversity in hypersaline environments. Extremophiles 2: 297-304. 
10. Litchfield CD, Oren A, (2001) Polar lipids and pigments as biomarkers for the study of the microbial community structure of solar salterns. Hydrobiologia 466: 81-89.

11. Ochsenreiter T, Pfeifer F, Schleper C (2002) Diversity of Archaea in hypersaline environments characterized by molecular-phylogenetic and cultivation studies. Extremophiles 6: 267-274.

12. Mutlu MB, Martínez-García M, Santos F, Peña A, Guven K, et al. (2008) Prokaryotic diversity in Tuz Lake, a hypersaline environment in Inland Turkey. FEMS Microbiol Ecol 65: 474-483.

13. Norton C (1992) Rediscovering the ecology of halobacteria. ASM News 58: 363-367.

14. Anton J, Llobet-Brossa E, Rodriguez-Valera F, Amann R (1999) Fluorescence in situ hybridization analysis of the prokaryotic community inhabiting crystallizer ponds. Environ Microbiol: 517-523.

15. Dyall-Smith M (2004) The Halohandbook.

16. Foster NS, Thompson SE, Valentine NB, Amonette JE, Johnson TJ (2004) Identification of sporulated and vegetative bacteria using statistical analysis of fourier transform mid-infrared transmission data. Appl Spectrosc 58: 203-211.

17. Helm D, Labischinski H, Naumann D (1991) Elaboration of a procedure for identification of bacteria using Fourier-transform IR spectral libraries: a stepwise correlation approach. J Microbiol Meth 14: 127-142.

18. Orsini F, Ami D, Villa AM, Sala G, Bellotti MG, et al. (2000) FT-IR microspectroscopy for microbiological studies. J Microbiol Methods 42: 17-27.

19. Ngo-Thi NA, Kirschner C, Naumann D (2003) Characterization and identification of microorganisms by FT-IR microspectrometry. J Mol Struct 37: 661-662.

20. Naumann D, Helm D, Labischinski H (1991) Microbiological characterizations by FT-IR spectroscopy. Nature 351: 81-82.

21. Helm D, Labischinski H, Schallehn G, Naumann D (1991) Classification and identification of bacteria by Fourier-transform infrared spectroscopy. J Gen Microbiol 137: 69-79.

22. Beattie SH, Holt C, Hirst D, Williams AG (1998) Discrimination among Bacillus cereus, B. mycoides and B. thuringiensis and some other species of the genus Bacillus by Fourier transform infrared spectroscopy. FEMS Microbiol Lett 164: 201-206.

23. Filip Z, Hermann S (2001) An attempt to differentiate Pseudomonas spp., and other soil bacteria by FT-IR spectroscopy. Eur J Soil Biol 37: 137-143.

24. Guibet F, Amiel C, Cadot P, Cordevant C, et al. (2003) Discrimination and classification of Enterococci by FT-IR. Vib Spectrosc 33: 133-142.

25. Lin M, Al-Holy M, Al-Qadiri H, Kang DH, Cavinato AG, et al. (2004) Discrimination of intact and injured Listeria monocytogenes by Fourier transform infrared spectroscopy and principal component analysis. J Agric Food Chem 52: 5769-5772.

26. van der Mei HC, Naumann D, Busscher HJ (1993) Grouping of oral streptococcal species using fourier-transform infrared spectroscopy in comparison with classical microbiological identification. Arch Oral Biol 38: 1013-1019.

27. Filip Z, Herrmann S, Kubat J (2004) FT-IR spectroscopic characteristics of differently cultivated Bacillus subtilis. Microbiol Res 159: 257-262.

28. Oust A, Møretrø T, Kirschner C, Narvhus JA, Kohler A (2004) FT-IR spectroscopy for identification of closely related lactobacilli. J Microbiol Methods 59: 149-162.

29. Winder CL, Carr E, Goodacre R, Seviour R (2004) The rapid identification of Acinetobacter species using Fourier transform infrared spectroscopy. J Appl Microbiol 96: 328-339.

30. Essendoubi M, Toubas D, Bouzaggou M, Pinon JM, Manfait M, et al. (2005) Rapid identification of Candida species by FT-IR microspectroscopy. Biochim Biophys Acta 1724: 239-247.

31. Al-Holy MA, Lin M, Al-Quadiri H, Cavinato AG, et al. (2006) Discrimination of foodborne pathogens by Fourier transform infrared spectroscopy and principal component analysis. J Rapid Meth Au Mic 14: 189-200.
32. Mouwen DJ, Capita R, Alonso-Calleja C, Prieto-Gómez J, Prieto M (2006) Artificial neural network based identification of Campylobacter species by Fourier transform infrared spectroscopy. J Microbiol Methods 67: $131-140$.

33. Lamprell H, Mazerolles G, Kodjo A, Chamba JF, Noël Y, et al. (2006) Discrimination of Staphylococcus aureus strains from different species of Staphylococcus using Fourier transform infrared (FTIR) spectroscopy. Int J Food Microbiol 108: 125-129.

34. Sandt C, Madoulet C, Kohler A, Allouch P, De Champs C, et al. (2006) FT-IR microspectroscopy for early identification of some clinically relevant pathogens. J Appl Microbiol 101: 785-797.

35. Dziuba B, Babuchowski A, Nałęcz D, Niklewicz M (2007) Identification of lactic acid bacteria using FTIR spectroscopy and cluster analysis. Int Dairy J 17: 183-189.

36. Oust A, Møretrø T, Naterstad K, Sockalingum GD, Adt I, et al. (2006) Fourier transform infrared and raman spectroscopy for characterization of Listeria monocytogenes strains. Appl Environ Microbiol 72: 228-232.

37. Amiali NM, Mulvey MR, Berger-Baochi B, Sedman J, et al. (2008) Evaluation of Fourier transform infrared spectroscopy for the rapid identification of glycopeptide-intermediate Staphylococcus aureus. J Antimicrob Chemother 61: 95-102.

38. Garip S, Bozoglu F, Severcan F (2007) Differentiation of mesophilic and thermophilic bacteria with fourier transform infrared spectroscopy. Appl Spectrosc 61: 186-192.

39. Alexandrakis D, Downey G, Scannell AG (2008) Detection and identification of bacteria in an isolated system with near-infrared spectroscopy and multivariate analysis. J Agric Food Chem 56: 3431-3437.

40. Preisner O, Lopes JA, Menezes JC (2008) Uncertainty assessment in FTIR spectroscopy based bacteria classification models. Chemom Intell Lab Syst 94: 33-42.

41. Forrester JB, Valentine NB, Su YF, Johnson TJ (2009) Chemometric analysis of multiple species of Bacillus bacterial endospores using infrared spectroscopy: discrimination to the strain level. Anal Chim Acta 651: 24-30.

42. Mietke H, Beer W, Schleif J, Schabert G, et al. (2010) Differentiation between probiotic and wild-type Bacillus cereus isolates by antibiotic susceptibility test and Fourier transform infrared spectroscopy (FT-IR). Int J Food Microbiol 140: 57-60.

43. Santos LM, Simoes ML, Melo WJ, Neto LM, et al. (2010) Applications of chemometric methods in the evaluation of chemical and spectroscopic data on organic matter from Oxisols in sewage sludge applications. Geoderma 155: 121-127.

44. Samelis J, Bleicher A, Delbès-Paus C, Kakouri A, Neuhaus K, et al. (2011) FTIR-based polyphasic identification of lactic acid bacteria isolated from traditional Greek Graviera cheese. Food Microbiol 28: 76-83.

45. Davis R, Paoli G, Mauer LJ (2012) Evaluation of Fourier transform infrared (FT-IR) spectroscopy and chemometrics as a rapid approach for sub-typing Escherichia coli O157:H7 isolates. Food Microbiol 31: 181-190.

46. Preisner OE, Menezes JS, Guiomar R, Machado J, Lopes JA (2012) Discrimination of Salmonella enterica serotypes by Fourier transform infrared spectroscopy. Food Res Int 45: 1058-1064.

47. Ergin Ã, Älkit M, GÃgk Y, Ãzel MZ, Ãon AH, et al. (2013) Fourier transform infrared spectral evaluation for the differentiation of clinically relevant Trichophyton species. J Microbiol Methods 93: 218-223.

48. de Sousa Marques A, de Melo MCN, Cidral TA, de Lima KMG (2014) Feature selection strategies for identification of Staphylococcus aureus recovered in blood cultures using FT-IR spectroscopy successive projections algorithm for variable selection: A case study. J Microbiol Meth 98: 26-30.

49. Lecellier A, Gaydou V, Mounier J, Hermet A, Castrec L, et al. (2015) Implementation of an FTIR spectral library of 486 filamentous fungi strains for rapid identification of molds. Food Microbiol 45: 126-134.

50. Kirkwood J, Al-Khaldi SF, Mossoba MM, Sedman J, Ismail AA (2004) Fourier transform infrared bacteria identification with the use of a focal- 
Citation: Güven K, Albayrak G, Güven A, Yazic B (2015) FT-IR for Rapid Discrimination of Halophilic Archaea and Bacteria. J Phylogen Evolution Biol 3: 145. doi:10.4172/2329-9002.1000147

Page 7 of 7

plane-array detector and microarray printing. Appl Spectrosc 58 1364-1368.

51. Subramanian A, Rodriguez-Saona LE (2009) Fourier transform infrared (FTIR) spectroscopy. In Infrared Spectroscopy for Food Quality Analysis and Control. Elsevier, Amsterdam, pp.145-178.

52. Rebuffo AC, Schmitt J, Wenning M, Stetten F, et al., (2006) Reliable and rapid identification of Listeria monocytogenes and Listeria species by artificial neural network-based Fourier transform infrared spectroscopy Appl Environ Microbiol 72: 994-1000.
53. Samuels AC, Snyder AP, Emge DK, Amant D, Minter J, et al. (2009) Classification of select category A and B bacteria by Fourier transform infrared spectroscopy. Appl Spectrosc 63: 14-24.

54. Burgula Y, Khali YD, Kim S, Krishnan SS, et al., (2007) Review of midinfrared Fourier transform-infrared spectroscopy applications for bacterial detection. J Rapid Meth Aut Mic 15: 146-175. 